Katarzyna JEDYNAKIEWICZ-MRÓZ

Uniwersytet Łódzki

jedmroz@uni.lodz.pl

\title{
POD CIĘŻAREM NIEMIECKIEJ HISTORII
}

\author{
GENERACJA WNUKÓW WOBEC NARODOWO- \\ SOCJALISTYCZNEJ PRZESZŁOŚCI SWYCH RODZIN - \\ PRÓBA CHARAKTERYSTYKI TRENDÓW I POSTAW
}

\section{ABSTRACT The Burden of German History}

The article is an attempt to describe the contemporary forms of the overcoming of the Nazi Past by the generation of the grandchildren. The presentation is based on the newest publications of the representatives of this group, as well as on the studies of the specialists. The first part of the article shows the defensive mechanisms accompanying the process of confrontation with the family part of the Nazi history. The second one presents the forms of an active and critical confrontation with the Nazi past of the generation of the grandparents, using the example of the six representatives of their grandchildren.

Key-words: the grandchildren of the Nazi Perpetrators, the overcoming of the Nazi past

Słowa kluczowe: wnuki nazistowskich Sprawców, przezwyciężanie nazistowskiej przeszłości

roblem pamięci w kontekście historii Niemiec XX w. ma swoją specyfikę - stanowi
nieodłączną czesśc procesu rozliczeń z nazistowska przeszłością tego kraju, zarówno w wymiarze publicznym (via deklaracje polityków, programy szkolne, media), jak i prywatnym - rodzinnym. Do lat 60. dyskurs publiczny uwarunkowany był odmiennością ideologiczną dwóch państw niemieckich. W NRD obowiązywała teza o „anty- 
faszystowskich zwykłych Niemcach” i nazistowskiej „oligarchii”, której przedstawiciele mieli nadal dzierżyć władzę w sąsiedniej RFN. Z kolei w Republice Bońskiej obowiązywała zasada "grubej kreski” w odniesieniu do niedawnej przeszłości i postulat skupienia wysiłków na budowie „cudu gospodarczego”. Dopiero dojście do głosu generacji '68 zapoczątkowało nad Renem publiczną dyskusję nad dziedzictwem nazizmu, także w kontekście kontrowersyjnych biografii członków zachodnioniemieckiego establishmentu. Problem polegał na tym, że za retorycznymi pytaniami o przeszłość pokolenia rodziców rzadko szły rozmowy w rodzinnych domach i wśród bliskich ${ }^{1}$. Przełamanie tabu $\mathrm{w}$ aspekcie osobistym okazało się znacznie trudniejsze niż zanegowanie nazistowskiego dziedzictwa w wymiarze publicznym. W efekcie owych trudności RFN uporała się wprawdzie z bagażem historycznej odpowiedzialności za III Rzeszę, jednak jej obywatele nadal funkcjonowali w swoistym rozdwojeniu: szczerze potępiając państwo Hitlera, nie przekładali tego na prywatne wspomnienia z lat 1933-1945².

Warto podkreślić, iż wspomniana dychotomia dotyczyła nie tylko Niemiec Zachodnich. Także w NRD unikano osobistej konfrontacji z postawą przodków - tym bardziej że niezgodna z linią ideologiczną przeszłość rodziców mogła oznaczać polityczne problemy dla ich dzieci. Częstą strategią było nie tylko unikanie rozmów o przeszłości, ale także jej „koloryzowanie” na potrzeby publiczne - wedle zasady „podwójnego języka”, doskonale znanej we wszystkich krajach Bloku Wschodniego3.

Jeszcze początkiem lat 90. unikanie konfrontacji z rodzinną pamięcią czasów nazizmu wydawało się w Niemczech tendencją trwałą. W sferze publicznej tematem numer jeden stało się rozliczenie dziedzictwa komunizmu, będące następstwem upadku NRD i zjednoczenia dwóch państw niemieckich. Wprawdzie fakt podobieństw obu totalitaryzmów ożywił świadomość niedostatku rodzinnego „przepracowania” nazistowskiej przeszłości, ale podjęcie owego wątku natrafiało nadal na bariery emocjonalne, zarówno ze strony pokolenia dzieci, jak i samych „świadków” III Rzeszy.

Dla generacji '68 istotną rolę w przełamywaniu tabu odegrały badania izraelskiego psychologa Dana Bar-Ona, prowadzącego od lat 80. badania nad pamięcią potomków „sprawców” i „ofiar” narodowego socjalizmu. W wydanej w Niemczech w 1993 r. pracy Dziedzictwo milczenia (niemiecki tytuł Last des Schweigens, czyli Ciężar milczenia) opublikował on wyniki swych rozmów z dziećmi nazistów ${ }^{4}$. Książka wywołała w RFN

$1 \quad$ S. Bode, Kriegsenkel. Die Erben der vergessenen Generation, Stuttgart 2013, s. 176.

2 Jednym z nielicznych wyjątków od opisanej reguły była książka Niklasa Franka, stanowiąca emocjonalne rozliczenie z ojcem - szefem Generalnego Gubernatorstwa, Hansem Frankiem (Mein Vater. Eine Abrechnung, München 1987; wydanie polskie z 1991 r.). Pracy Franka nie można jednak interpretować w kategoriach konfrontacji „bezpośredniej”, bowiem autor nie miał możliwości rozmowy ojcem o jego postawie w czasach nazizmu.

3 H. Welzer, S. Moller, K. Tschuggnall, „Opa warkein Nazi”. Holocaust im Familiengedächtnis, Frankfurt am Main 2002, s. 167-168, Zeit des Nationalsozialismus.

4 D. Bar-On, Die Last des Schweigens. Gespräche mit Kindern von Nazi-Tätern, Reinbek bei Hamburg 2003. Dan Bar-On (1938-2008) prowadził początkowo terapię potomków ofiar Holokaustu. Jego prowadzone od 1985 r. w RFN rozmowy z dziećmi „sprawców” zaowocowały nie tylko książką Legacy of Silence (1989), ale też dialogiem między potomkami obu badanych grup - zarówno w RFN, jak i w Izraelu. W 2001 r. Dan Bar-On został odznaczony niemieckim Federalnym Krzyżem Zasługi. 
znaczący rezonans, stając się impulsem dla podobnej konfrontacji w rodzinach „zwykłych" Niemców.

Zasadniczą zmianę w procesie „odpominania” czasów III Rzeszy przyniósł dopiero przełom pokoleniowy początków XXI w. Do rozmów rodzinnych włączyła się wówczas generacja wnuków - osoby urodzone w latach 60. i 70. XX stulecia. Ich potrzebie poznania przeszłości bliskich towarzyszyła ewolucja postawy pokolenia „świadków” epoki nazizmu. Ci ostatni zaczęli sobie uświadamiać upływający czas i ryzyko związane z niemożnością podzielenia się z bliskimi wspomnieniami z młodości. Ciekawym zjawiskiem po stronie generacji „dziadków” okazała się tendencja do podejmowania rozmów nie z własnymi dziećmi, lecz właśnie z wnukami - teoretycznie bardziej zdystansowanymi wobec „uwikłania” swych bliskich w narodowy socjalizm5. Nie oznaczało to wyłączenia z dialogu przedstawicieli generacji '68, a jedynie przeniesienie ciężaru „odpominania” przeszłości na drugą generację potomków III Rzeszy.

Pierwsze efekty rodzinnych debat międzypokoleniowych w RFN ukazała książka „Opa war kein Nazi”. Nationalsozialismus und Holocaust im Familiengedächtnis, opublikowana w roku 2002. Stanowiła ona efekt trzyletnich prac zespołu naukowego, pracującego pod kierunkiem psychologa społecznego Haralda Welzera ${ }^{6}$. Autorzy projektu postawili sobie za cel odpowiedź na pytania, jak „zwykli” Niemcy wspominają czasy III Rzeszy i jaki obraz przeszłości przekazują swym potomkom. Do analizy wybrano tzw. normalne rodziny, niemające w swym gronie osób obciążonych karnie za zbrodnie nazizmu. Formę badania stanowiły wywiady indywidualne oraz wspólne rozmowy z przedstawicielami trzech rodzinnych generacji: „świadków”, dzieci oraz wnuków. W badaniu uczestniczyło 30 rodzin z dawnej RFN i 10 rodzin z byłej NRD.

Wyniki badawcze zespołu Welzera okazały się pouczające, nie tyle w kontekście postawy pokolenia świadków, ile ich wnuków. W odróżnieniu od generacji '68, świadomie unikającej zgłębiania przeszłości własnych rodziców (ze strachu, co usłyszą), generacja wnuków wykazała otwartość nawet na kontrowersyjne fragmenty przeszłości swych przodków. Zaskakującą tendencją w rozmowach była wręcz reinterpretacja słów dziadków, zmierzająca w kierunku usprawiedliwiania ich zachowań w czasach III Rzeszy. Rehabilitowanie przybierało formę nie tylko relatywizacji odpowiedzialności czy postrzegania bliskich w kategoriach ofiar (wojny, bombardowań, gwałtów, powojennych wysiedleń). Niekiedy, nawet wbrew intencjom autorów opowiadań, dochodziło wręcz do heroizowania czynów dziadków, takich jak np. niedonoszenie na Gestapo, interpretowane jako przejaw przynależności do ruchu oporu ${ }^{7}$. W przypadku wnuków z byłej NRD szukanie okoliczności łagodzących miało swoją specyfikę. Osoby te znały z autopsji uwarunkowania życia w totalitaryzmie, charakterystyczną dla tego systemu uniformizację zachowań i oportunistyczne dostosowywanie się do oczekiwań reżimu.

H. Welzer, S. Moller, K. Tschuggnall, „Opa war kein Nazi”..., s. 26.

6 W 2010 r. na rynku polskim ukazała się praca Welzera pt. Sprawcy. Dlaczego zwykli ludzie dokonują masowych mordów? (niemieckie wydanie z 2005 r.), analizująca postawy wykonawców polityki Zagłady.

7 H. Welzer, S. Moller, K. Tschuggnall, „Opa war kein Nazi”..., s. 53-54, 206-207.

8 Tamże, s. 183-184. 
Badania zespołu Welzera ujawnity z jednej strony rozziew między „obiektywną” wiedzą historyczną a historią w wydaniu rodzinnym, z drugiej zaś siłę oddziaływania rodzinnych narracji. Okazało się, że opowiadania dziadków, przenikające do świadomości wnuków niejako en passant (przy okazji zabaw, rodzinnych uroczystości itp.) zapadały w pamięć znacznie silniej niż obrazy przekazywane za pośrednictwem szkoły, książek czy dokumentalnych obrazów filmowych. Szczególnie symptomatyczną siłę rodzinnego przekazu ujawniały wypowiedzi osób urodzonych w latach 80. („późne wnuki”, prawnuki), dorastających w początkach ery Internetu. Te ostatnie wykazywały wręcz znudzenie tradycyjną edukacją, preferując nieformalne (a więc także rodzinne) formy przekazu?.

Opisane przez zespół Welzera skutki konfrontacji wnuków ze wspomnieniami dziadków nie oznaczały, jak mogłoby się wydawać, tendencji do usprawiedliwiania przez przedstawicieli młodszego pokolenia narodowego socjalizmu czy rewidowania ocen III Rzeszy. Wręcz przeciwnie, badania wykazały korelację między stopniem potępiania nazistowskiej przeszłości a tendencją do usprawiedliwiania (lub wręcz heroizowania) własnych bliskich. Wspomniana zależność była tym silniejsza, im bliższa była więź emocjonalna z dziadkami. Pamięć ciepła i miłości okazywanej w dzieciństwie czyniła niezwykle trudnym zaakceptowanie prawdy o pronazistowskiej postawie czy kontrowersyjnym zachowaniu tych ostatnich ${ }^{10}$.

Wnioski autorów książki „Opa war kein Nazi” potwierdził sondaż Emnid Institut z Bielefeld, przeprowadzony w czerwcu 2002 r. W świetle jego wyników 49\% obywateli Niemiec postrzegało swych żyjących w III Rzeszy bliskich jako nastawionych „negatywnie" do nazistowskiego reżimu. Zaledwie $6 \%$ ankietowanych określiło postawę swych rodzin jako „zdecydowanie” lub „raczej” pronazistowską. Sondaż wykazał także związek między poziomem wykształcenia a pozytywną oceną bliskich ( $56 \%$ osób posiadających maturę uznało swych przodków za oponentów reżimu $)^{11}$.

Wyniki ankiety oraz wywiadów zespołu Welzera wyzwoliły nie tylko falę dyskusji nad „fenomenem nazizmu bez nazistów”. Dla części reprezentantów pokolenia wnuków stały się one impulsem do własnych badań nad przeszłością przodków, nie w celu ich usprawiedliwiania, lecz z potrzeby stawienia czoła rodzinnej przeszłości. Niektórzy przedstawiciele wspomnianej grupy zdecydowali się upublicznić wyniki swych poszukiwań $w$ formie książek. W ten sposób na rynku wydawniczym RFN pojawił się nowy typ literatury wspomnieniowej: osobiste i często bolesne konfrontacje z postaciami przodków. Autorami tych prac były zresztą nie tylko wnuki, ale także dzieci nazistów, nierzadko prominentnych przedstawicieli elity III Rzeszy. Można tu wymienić Martina Bormanna juniora, Richarda von Schiracha, Thomasa Harlana, córkę Alberta Speera - Margaret Nissen ${ }^{12}$. Różnicę między obu grupami potomków stanowiła kwe-

\section{Tamże, s. 72.}

10 Tamże, s. 53, 76-78.

11 Tamże, s. 246.

12 Książka Bormanna juniora ukazała się w RFN już w 1996 r. Prace Richarda von Schiracha i Margaret Nissen zostały opublikowane w 2005 r., zaś Thomasa Harlana w 2007 r. 
stia stosunku do opisywanych osób. Żaden spośród autorów(-ek) należących do generacji wnuków nie pamiętał swych dziadków, bowiem zmarli oni przed ich narodzeniem lub w ich wczesnym dzieciństwie. Ów brak osobistej pamięci, a zarazem więzi emocjonalnej z dziadkami ułatwiał, przynajmniej początkowo, podjęcie dyskusji w gronie bliskich na temat przeszłości ich rodzin.

Pierwszą publikacją prezentującą wyniki konfrontacji z postaciami dziadków była praca Claudii Brunner i Uwe von Seltmanna pt. Schweigen die Täter, reden die Enkel (Milcza sprawcy, mówia wnuki), opublikowana w RFN w 2005 r. ${ }^{13}$ Claudia Brunner podążyła w książce śladami swego stryjecznego dziadka, esesmana Aloisa Brunnera, który jako współpracownik Adolfa Eichmanna nadzorował deportacje do obozów zagłady greckich, francuskich i słowackich Żydów. Z kolei Uwe von Seltmann opisał proces „odpominania” biografii dziadka Lothara von Seltmanna, również członka SS i jednego z podwładnych dowódcy policji w dystrykcie lubelskim Generalnego Gubernatorstwa - Odilo Globocnika.

Dwa lata po publikacji pracy Schweigen die Täter... ukazały się książki Alexandry Senfft oraz Karla Otto Saura i Michaela Saura. Pierwsza z wymienionych pozycji, nosząca tytuł Schweigen tut weh (Milczenie sprawia ból), prezentowała proces konfrontacji z rodzinną historią wnuczki Hannsa Ludina, w latach 1941-1945 posła III Rzeszy na Słowacji, nadzorującego z ramienia Auswärtiges Amt wywózki tamtejszych Żydów do obozu w Auschwitz-Birkenau ${ }^{14}$. Z kolei praca Saurów, zatytułowana Er stand im Hitlers Testament (Widniat $w$ testamencie Hitlera), stanowiła dwugeneracyjną (syna i wnuka) rozprawę z pamięcią po Karlu-Otto Saurze seniorze. Ten ostatni był jednym z zastępców Alberta Speera, ministra uzbrojenia w latach 1942-1945, i jako taki współodpowiadał za pracę więźniów obozów koncentracyjnych w niemieckich fabrykach podczas wojny ${ }^{15}$.

W proces publicznego rozrachunku z pamięcią wpisywała się także opublikowana w 2013 r. praca Jennifer Teege pt. Amon. Mein Grossvater hätte mich erschossen, będąca zapisem mierzenia się z przeszłością wnuczki Amona Götha - sadystycznego komendanta obozu pracy w Krakowie-Płaszowie, uwiecznionego w filmie Stevena Spielberga Lista Schindlera ${ }^{16}$. Pozycję autorki książki należy uznać za szczególnie trudną, bowiem swe korzenie poznała jako osoba dorosła, na dodatek - z racji koloru skóry i nieślubnego pochodzenia (jest dzieckiem Moniki Göth i studiującego w Niemczech Nigeryjczyka) - obciążona dodatkową traumą.

13 Polskie wydanie jest połączeniem wspomnianej książki oraz pracy Uwe von Seltmanna pt. Todleben. Eine deutsch-polnische Suche nach der Vergangenheit, Müchen 2010, i zostało opublikowane pod tytułem Gabi i Uwe. Mój dziadek zginąt w Auschwitz. A mój byt esesmanem (Warszawa 2012, Pokolenie Sprawców. Pokolenie Ofiar. Literatura Faktu PWN).

14 A. Senfft, Schweigen tut weh. Eine deutsche Familiengeschichte, Berlin 2009.

15 K.O. Saur, M. Saur, Er stand im Hitlers Testament. Ein deutsches Familienerbe, Berlin 2007. O zasługach Saura seniora świadczył fakt umieszczenia go w „ostatniej woli” Hitlera w charakterze członka gabinetu Karla Dönitza - jako następcy Speera na stanowisku ministra uzbrojenia III Rzeszy.

16 J. Teege, Amon. Mein Grossvater hätte mich erschossen, Reinbek bei Hamburg 2013, Sachbuch BV, 06493. W języku polskim książka ukazała się w roku 2014 pt. Amon. Mój dziadek by mnie zastrzelit. W artykule korzystałam z wydania niemieckiego. 
Uzupełnienie książkowych narracji stanowił także wyprodukowany w 2005 r. dokumentalny film Jensa Schanze, zatytułowany Winterkinder. Die schweigende Generation (Zimowe dzieci. Milczaca generacja). Autor filmu przedstawił w nim rodzinny proces konfrontacji z osobą dziadka ze strony matki, Wilhelma Schülke - inżyniera w kopalni w Neurode (dziś Nowa Ruda) na Dolnym Śląsku i instruktora politycznego NSDAP ${ }^{17}$.

Warto podkreślić, że wymienieni autorzy nie wyczerpują listy osób dokonujących w ostatnich latach wiwisekcji nazistowskiej rodzinnej przeszłości. W grupie tej znalazły się także wnuki przywódców III Rzeszy: Katrin Himmler i Bettina Göring (stryjeczne wnuczki Himmlera i Göringa) oraz stryjeczny wnuk Göringa, Matthias Göring. Ich sposób konfrontacji z rodowym dziedzictwem nie był jednak przełamywaniem tabu, lecz formą radzenia sobie z faktem noszenia eksponowanego nazwiska ${ }^{18}$. Tylko w przypadku Katrin Himmler przyjęła ona postać monografii prezentującej Heinricha Himmlera i jego braci. W odróżnieniu od wymienionych wcześniej pozycji, książka nie nosiła charakteru rozliczeniowego, mimo intencji naświetlenia także nazistowskiej przeszłości dziadka autorki ${ }^{19}$.

W odróżnieniu od potomków Himmlera czy Göringa sytuacja omawianych w artykule autorów była bezpieczniejsza. Ich dziadkowie nie należeli do ścisłej elity III Rzeszy, zaś ich nazwiska nie były powszechnie znane ${ }^{20}$. W przypadku Jennifer Teege narzędzie ochrony tożsamości stanowił także kolor skóry. Inaczej niż wnuczki i wnuki Göringa i Himmlera autorzy analizowanych publikacji nie musieli tłumaczyć się z faktu posiadania w rodzinie nazisty (Alexandrę Senfft i Jennifer Teege chroniło dodatkowo inne nazwisko ${ }^{21}$. Ich anonimowość została złamana wskutek własnej decyzji, w momencie podjęcia badań nad historią dziadków oraz - w ostatecznym rozrachunku w momencie publikacji książki ${ }^{22}$.

Zarówno autorzy wymienionych prac, jak i reżyser filmu należeli do pokolenia wnuków, urodzonego w latach 60. i 70. XX stulecia ${ }^{23}$. Poza Claudią Brunner, która swe poszukiwania rozpoczęła jako 27-letnia studentka politologii na uniwersytecie w Wiedniu, wszyscy pozostali zdecydowali się zmierzyć z rodzinną przeszłością po 30 roku

17 Winterkinder. Die schweigende Generation, reż. J. Schanze, 2005. Film miał prapremierę na Międzynarodowym Festiwalu filmów Dokumentalnych w Monachium.

18 O skali traumy związanej z faktem bycia potomkiem jednego z przywódców III Rzeszy świadczą decyzje Bettiny i Matthiasa Göringów. Żadne z wymienionych nie mieszka w Niemczech; Bettina Göring poddała się sterylizacji, zaś Matthias Göring stał się badaczem Tory.

19 Opublikowana w 2005 r. w RFN książka nosiła tytuł Die Brüder Himmler. Wydanie polskie (2006) nosiło tytuł Himmler i jego bracia.

20 Wprawdzie postać Aloisa Brunnera była dobrze znana historykom, jednak popularność tego nazwiska w Austrii utrudniała rozszyfrowanie tożsamości jego potomków. Zob.: C. Brunner, U. von Seltmann, Schweigen die Täter, reden die Enkel, Frankfurt am Main 2005, s. 17.

${ }^{21}$ Alexandra Senfft jest wnuczką Hannsa Ludina po matce i nosi nazwisko ojca, Jennifer Teege używa nazwiska męża.

22 Przyjaciele Alexandry Senfft znali przeszłość jej dziadka, ale nie upubliczniali tego faktu.

23 W latach 60. urodzili się: Alexandra Senfft (1961), Uwe von Seltmann (1964) i Michael Saur (1967), zaś w latach 70.: Jennifer Teege (1970), Jens Schanze (1971) oraz Claudia Brunner (1972). Karl-Otto Saur junior urodził się w $1944 \mathrm{r}$. 
życia. Całą grupę łączyło zainteresowanie historią oraz ciekawość badawcza, po części stanowiąca atrybut wykształcenia i/lub wykonywanego zawodu ${ }^{24}$. Wspólną cechą sześciorga autorów był nie tylko poznawczy, ale i emocjonalny kontekst zajęcia się postacią dziadków - potrzeba przezwyciężenia „rodzinnych bólów fantomowych” poprzez przełamanie bariery milczenia wokół losu przodków ${ }^{25}$. Konfrontacja dotyczyła nie tylko dziadków, ale i rodziców - owej „milczącej generacji” z tytułu filmu Jensa Schanze. W przypadku książki Saurów przybrało to postać równoległej narracji syna i wnuka, zaś w pracy Alexandry Senfft - symbolicznej rozmowy z nieżyjącą matką.

Autorów analizowanych prac łączy sytuacja wyjściowa: brak emocjonalnej więzi z dziadkami. W niektórych przypadkach było to konsekwencją kolei życiowych tych ostatnich. Amon Göth został skazany na śmierć i stracony w Polsce w 1946 r., Hannsa Ludina osądzono i stracono w 1947 r. w Czechosłowacji. Alois Brunner ukrywał się po wojnie na terenie Niemiec, a następnie zbiegł do Syrii. Lothar von Seltmann prawdopodobnie zginą zimą 1945 r., walcząc w jednostce frontowej SS na Dolnym Śląsku. Także Wilhelm Schülke i Karl-Otto Saur senior nie poznali swych wnuków - pierwszy z wymienionych zginął w wypadku samochodowym w 1954 r., drugi zmarł w 1966 r.

Wszyscy autorzy omawianych książek dorastali, nie mając wiedzy o dziadkach. Jennifer Teege dowiedziała się, że jest wnuczką Amona Götha, w 38 roku życia ${ }^{26}$. Uwe von Seltmann i Jens Schanze (a także ich rodzeństwo) nie drążyli wątku rodzinnej przeszłości, dostrzegając nerwowe reakcje rodziców na wzmianki o niej. Ci ostatni nie poruszali tematu, wstydząc się nazistowskich przodków. W przypadku matki Jensa Schanze głównym powodem milczenia (także wobec własnego męża) było specyficzne poczucie lojalności wobec zmarłego ojca - częsty motyw wymieniany w badaniach nad generacją dzieci nazistów ${ }^{27}$. Przypadki Alexandry Senfft i Claudii Brunner były bardziej skomplikowane. Rodzina tej pierwszej nigdy nie pogodziła się z wyrokiem na Hannsie Ludinie, interpretując go jako akt zemsty komunistycznego reżimu w Pradze. Głowę rodu postrzegano jako „dobrego nazistę" oraz ofiarę niemieckiego kultu wierności wobec państwa i jego przywódców ${ }^{28}$. W przypadku Claudii Brunner istotny problem stanowiła atmosfera niedopowiedzeń wokół ukrywającego się w Syrii stryjecznego dziadka. Część członków rodziny utrzymywała kontakt korespondencyjny z Aloisem Brunnerem co najmniej do końca lat $80 . \mathrm{XX} \mathrm{w}^{29}$

24 Alexandra Senfft, Uwe von Seltmann i Michael Saur są dziennikarzami, zaś Jens Schanze dokumentalistą filmowym. Jennifer Teege studiowała orientalistykę, zaś Claudia Brunner politologię i historię.

25 Pojęcie „rodzinne bóle fantomowe” zostało użyte przez Claudię Brunner, jako synonim pośredniej obecności w życiu rodzin nazistowskiej przeszłości. Zob.: C. Brunner, U. von Seltmann, Schweigen die Täter..., s. 8-9.

J. Teege, Amon..., s. 9, 13.

27 J. Müller-Hohagen, Geschichte in uns. Seelische Auswirkungen bei den Nachkommen von NS-Tätern und Mitläufern, Berlin 2002, s. 45-50.

28 A. Senfft, Schweigen tut weh..., s. 13-14.

29 Kontakt korespondencyjny z Aloisem Brunnerem utrzymywal także ojciec Claudii Brunner, a nawet (w okresie nastoletniości) ona sama. Zob.: C. Brunner, U. von Seltmann, Schweigen die Täter..., s. 76-79. 
Unikanie w domu rozmów na temat „kłopotliwego” członka rodu stosunkowo wcześnie zaczęło stanowić problem dla większości autorów analizowanych prac. Obok poczucia dysonansu między treścią przekazu publicznego a brakiem rodzinnego dyskursu na temat dziadka-nazisty, niepokój budziła sama tajemnica otaczająca przeszłość. Warto podkreślić, że rodzice wszystkich sześciorga autorów byli (są) szczerymi demokratami, a część aktywnie wspierała politykę rządu Willy’ego Brandta oraz ideę rozliczeń dziedzictwa III Rzeszy ${ }^{30}$.

Nie mając szansy na bezpośrednią konfrontację z rodzinnym tabu, większość członków omawianej grupy szukała własnej drogi „naprawy” swego pochodzenia, np. poprzez podróże do Polski (Seltmann) ${ }^{31}$, do Izraela (Senfft, Seltmann) ${ }^{32}$ lub też poprzez szukanie kontaktów ze środowiskiem żydowskim w Stanach Zjednoczonych (Michael Saur ${ }^{33}$. Także Jennifer Teege, nieświadoma w młodości swych biologicznych korzeni, zdecydowała się na studia nie w Niemczech, a w Izraelu, mimo że oznaczało to konieczność żmudnej nauki języka hebrajskiego ${ }^{34}$. Żadne z wymienionych (poza, z przyczyn oczywistych, Jennifer Teege) nie ukrywało rodzinnej przeszłości przed rówieśnikami, choć większość wybierała strategię „dawkowania prawdy” o swych dziadkach ${ }^{35}$.

U części analizowanych $\mathrm{w}$ artykule autorów ważną rolę w procesie dochodzenia do prawdy odegrał emitowany pod koniec 1979 r. w RFN amerykański serial Holocaust ${ }^{36}$. Po raz pierwszy w Niemczech Zachodnich pokazano wówczas konkretne, indywidualne losy rodziny niemieckich Żydów - ofiar nazistowskiej ideologii „rasowej”. Równie wstrząsająca w filmie była historia niemieckiego prawnika, który dla kariery staje się bezdusznym wykonawcą polityki Zagłady ${ }^{37}$.

Niektórzy z autorów książek powzięli decyzję o podjęciu badań nad rodzinną historią pod wpływem impulsu. W przypadku Uwe von Seltmanna taki przełom dokonał

30 Rodzice Alexandry Senfft byli zaprzyjaźnieni z rodziną Brandta, a na przyjęciach w ich domu bywali znani politycy SPD. Jej babcia Erla (wdowa po Hannsie Ludinie) do końca życia prenumerowała liberalną gazetę „Süddeutsche Zeitung”, zaś w życiu codziennym wykazywała otwartość wobec wielokulturowości etnicznej współczesnej RFN. Zmarła w 1997 r. Zob.: A. Senfft, Schweigen tut weh..., s. 305. Pierwszą podróż do Polski odbył jesienią 1989 r. razem z ojcem. Zob.: U. von Seltmann, Gabi i Uwe..., s. 18.

32 Alexandra Senfft pracowała w Izraelu z ramienia ONZ, Uwe von Seltmann mieszkał w tym kraju przez pół roku. Zob.: A. Senfft, Schweigen tut weh..., s. 300-301; U. von Seltmann, Gabi i Uwe..., s. 17.

33 Michael Saur „uciekl” od emocjonalnych zmagań swego ojca, wybierając studia w USA. Dziennikarską praktykę odbył w nowojorskiej, działającej od lat 30., żydowsko-niemieckiej gazecie „Aufbau”. Plonem pracy w tym periodyku były liczne kontakty z żydowskimi emigrantami z Niemiec oraz Żydami amerykańskimi. Zob.: K.O. Saur, M. Saur, Er stand im Hitlers Testament..., s. 201-202.

34 J. Teege, Amon..., s. 34-35, 214-216.

35 Najczęściej stosowanym przekazem informacyjnym było stwierdzenie: „Mój dziadek był nazistą”.

36 U. von Seltmann, Gabi i Uwe..., s. 19. Odmienne wspomnienia wobec serialu miat jedynie Michael Saur. Jego ocena nie dotyczyła samego filmu, ile powagi, z jaką ojciec podszedł do emisji (po projekcji nie pozwolił dzieciom na oglądanie innego, „rozrywkowego” filmu). Zob.: K.O. Saur, M. Saur, Er stand im Hitlers Testament..., s. 232-233.

37 W literaturze przedmiotu uważa się, że emisja filmu w RFN miała wpływ na ostateczną decyzję Bundestagu o nieprzedawnianiu zbrodni narodowego socjalizmu (1979). Zob.: P. Reichel, H. Schmid, P. Steinbach, Der Nationalsozialismus - die zweite Geschichte, München 2009, s. 307-308. 
się dzięki rozmowie z amerykańskim rabinem w synagodze na krakowskim Kazimie$\mathrm{rzu}^{38}$. Dla Alexandry Senfft czynnikiem inspirującym okazał się projekt jej wuja, reżysera Malte Ludina, polegający na nakręceniu dokumentalnego filmu o historii rodziny ${ }^{39}$. Jens Schanze podjął decyzję o zrobieniu filmu pod wpływem lektury wyników wspomnianego wcześniej sondażu z 2002 r. Najbardziej dramatycznie przedstawiały się motywy Jennifer Teege, która o rodzinnych korzeniach dowiedziała się z rozliczeniowej książki biologicznej matki, Moniki Göth ${ }^{40}$. W jej przypadku decyzja o konfrontacji z przeszłością dziadka oznaczała jednocześnie zmierzenie się ze wspomnieniami zapamiętanej z dzieciństwa babci, kochanki Götha z okresu, gdy był komendantem w obozie w Płaszowie ${ }^{41}$.

Wszyscy autorzy analizowanych w artykule książek zdobywali wiedzę w kilku etapach. Pierwszym i początkowo podstawowym źródłem informacji była lektura historycznych monografii i wspomnień z epoki ${ }^{42}$. Najwięcej bezpośrednich danych zdobyli ci, których dziadkowie odgrywali rolę publiczną w III Rzeszy (byli to: Hanns Ludin, Karl-Otto Saur, Amon Göth, Alois Brunner). W przypadku Uwe von Seltmanna i Jensa Schanze większość informacji pochodziła początkowo ze źródeł dokumentowych oraz gazet z epoki ${ }^{43}$. Dla części członków badanej grupy cenna okazała się korespondencja ich dziadków z rodziną. Niektórzy w trakcie poszukiwań dowiadywali się o przechowywaniu tych listów w domowych archiwach (Seltmann), inni wiedzieli o nich, ale dopiero teraz postanowili zmierzyć się z zawartą w tych źródłach wiedzą (Schanze). Równie ważnym przekazem historycznym okazały się fotografie, dokumentujące przebieg kariery przodka w służbie nazistowskiego reżimu. Szczególny szok przeżył w tym kontekście Uwe von Seltmann, widząc swego dziadka (i nieznaną babkę) u boku Himmlera, w trakcie wizytowania przez tego ostatniego volksdeutschów na Lubelszczyźnie ${ }^{44}$. W przypadku Jennifer Teege duże emocje wywołało obejrzenie dokumentalnego filmu Brytyjczyka Jona Blaira z 1983 r., z udziałem jej babci, Ruth Irene Göth ${ }^{45}$.

38 U. von Seltmann, Gabi i Uwe..., s. 16-19.

39 Efektem projektu był film Malte Ludina pt. 2 oder 3 Dinge, die ich von ihm weiss z 2005 r.

40 J. Teege, Amon..., s. 9, 14. W 2002 r. w RFN ukazała się książka Matthiasa Kesslera, będąca zapisem jego rozmów z Moniką Göth. Zob.: M. Kessler, „Ich muß doch meinen Vater lieben, oder?” Die Lebensgeschichte von Monika Göth, Tochter des KZ-Kommandanten aus „Schindlers Liste”, Frankfurt am Main 2002.

41 J. Teege, Amon..., s. 71, 81-83. Mimo pobytu w sierocińcu do siódmego roku życia Jennifer Teege miała kontakty zarówno z matką, jak i babką. Ta ostatnia nie poślubiła wprawdzie Amona Götha, ale za zgodą jego ojca przyjęła po wojnie nazwisko kochanka (druga żona Götha rozwiodła się z nim krótko po wojnie).

42 W przypadku Jennifer Teege, która najpóźniej z badanej grupy przystąpiła do badań nad historią dziadka, istotną rolę informacyjną odegrał też Internet. Zob.: tamże, s. 15.

43 Propagandowe mowy dziadka Jensa Schanze drukowała lokalna gazeta w Neurode. Artykuły promujące „niemiecką obecność” na ziemiach polskich autorstwa dziadka Uwe von Seltmanna ukazywały się w periodykach przeznaczonych dla volksdeutschów w Generalnej Guberni.

44 U. von Seltmann, Gabi i Uwe..., s. 54. Babka Seltmanna zmarła jesienią 1945 r. w wyniku choroby.

45 Dzień po udzieleniu wywiadu babka Jennifer Teege popełniła samobójstwo. Powodem decyzji była oficjalnie choroba obturacyjna płuc. Zob.: J. Teege, Amon..., s. 115-119. Film Blaira powstal jako element współpracy tego reżysera ze Stevenem Spielbergiem, zbierającym materiały do Listy Schindlera. 
Niektórzy z autorów analizowanych książek nawiązali także kontakty z kręgiem znajomych rodziny. Uwe von Seltmann poznał koleżankę szkolną dziadka na wieczorze autorskim, podczas którego prezentował swą powieśćc ${ }^{46}$. Jens Schanze dał ogłoszenie do prasy, odnajdując w ten sposób koleżankę z dzieciństwa swej matki.

Element procesu poznawania przeszłości dziadków stanowiły podróże do krajów i miejsc, w których odbywali oni swą służbę: do Polski (Seltmann, Teege, Schanze), Francji i Grecji (Brunner) oraz na Słowację (Senfft). Szczególny charakter miała wyprawa Jensa Schanze, który w podróż na Dolny Śląsk zabrał swych rodziców. Dla matki reżysera była to pierwsza wizyta w miejscu, które zapamiętała jako krainę szczęśliwego dzieciństwa i które dopiero teraz okazało się także miejscem gehenny ofiar nazizmu (teren byłego KZ Gross-Rosen, dziś Rogoźnica).

Widoczną składową poszukiwań autorów książek były pytania o motywy i uwarunkowania wyborów ich przodków. Nie mogąc znaleźć racjonalnej odpowiedzi, niektórzy próbowali stawiać się w sytuacji dziadków lub wyobrazić sobie rozmowę z nimi (Seltmann, Senfft, Michael Saur) ${ }^{47}$. Claudia Brunner cierpiała na nocne koszmary, w których spotykała stryjecznego dziadka ${ }^{48}$. Dla Jennifer Teege konfrontacja ze szczegółami życia Amona Götha zakończyła się konkluzją: Mój dziadek by mnie zastrzelitt ${ }^{49}$.

Interesujący wątek poszukiwań stanowily również pytania stawiane pod adresem babć. W odróżnieniu od dziadków przeżyły one wojnę i często były obecne w życiu swych wnuków. Jedynie Claudia Brunner nie poruszyła w książce tematu stryjecznej babki, nie napisała również o rodzonych dziadkach. Wszyscy z autorów prac deklarowali dyskomfort związany z pasywnością babć i akceptowaniem przez nie zachowania mężów. W przypadku Michaela Saura badania odświeżyły pamięć antysemickich wypowiedzi zasłyszanych podczas wizyt $\mathrm{w}$ domu dziadków ${ }^{50}$. Równie przykre emocje towarzyszyły przemyśleniom Jennifer Teege, nie mogącej zrozumieć, że babka biernie przyglądała się sadystycznym zachowaniom Götha ${ }^{51}$. Dla Alexandry Senfft konfrontacja z postawą babci oznaczała konieczność przełamania bariery lojalności i podania w wątpliwość dobrych wspomnień z dzieciństwa ${ }^{52}$.

Inny element analizy członków grupy stanowiły próby znalezienia w biografii dziadków okoliczności „odciążających”. Dla Uwe von Seltmanna takim faktem były starania jego przodka o przeniesienie w 1940 r. do Wehrmachtu ${ }^{53}$. Alexandra Senfft przywoła-

46 U. von Seltmann, Gabi i Uwe..., s. 21-22.

47 Tamże, s. 31; A. Senfft, Schweigen tut weh..., s. 119; K.O. Saur, M. Saur, Er stand im Hitlers Testament..., s. 112.

48 C. Brunner, U. von Seltmann, Schweigen die Täter..., s. 80.

49 J. Teege, Amon..., s. 56.

50 K.O. Saur, M. Saur, Er stand im Hitlers Testament..., s. 201.

51 J. Teege, Amon..., s. 44, 79, 103.

52 A. Senfft, Schweigen tut weh..., s. 16, 21, 219-220. Z uwagi na alkoholową chorobę swej matki (Eryka Ludin nigdy nie odzyskała emocjonalnej równowagi po śmierci ojca) autorka książki właśnie babcię postrzegała jako „opokę” okresu młodości.

53 Nota bene spowodowane nie rozczarowaniem do SS, tylko chęcią walki na froncie zamiast "gnicia” w pracy administracyjnej na Wschodzie. Zob.: U. von Seltmann, Gabi i Uwe..., s. 134-135. 
ła na kartach książki pozytywne świadectwo Kurta Hahna, twórcy gimnazjum w Salem. $\mathrm{Z}$ racji żydowskiego pochodzenia i postawy politycznej musiał on w $1933 \mathrm{r}$. opuścić Niemcy, a w wyjeździe miał mu pomóc właśnie Hanns Ludin ${ }^{54}$. Z kolei dziadek Jensa Schanze został w lutym 1945 r. wykluczony z partii za odesłanie na zachód swej rodziny, mimo obowiązującego mieszkańców Dolnego Śląska zakazu ewakuacji ${ }^{55}$. Nawet Jennifer Teege, obciążona w stopniu szczególnym jako potomkini dziadka-sadysty, próbowała znaleźć w osobowości Götha elementy „normalności”. Te ostatnie, jak choćby oportunizm i sybarytyzm, upodabniały go do jego adwersarza z filmu Spielberga, Oskara Schindlera ${ }^{56}$.

Należy podkreślić, że wspomniane wyżej zabiegi odciążające tylko pozornie przypominały mechanizm zachowań opisany w pracy Opa war kein Nazi. W przypadku autorów prezentowanych książek analiza zawsze prowadziła do konkluzji o braku usprawiedliwienia dla czynów przodka. Owa świadomość bezsporności winy dziadków prowadziła w rezultacie do poważnego kryzysu psychicznego u ich wnuków. Niektórzy (Seltmann, Brunner, Teege) przerywali na jakiś czas poszukiwania, nie mogąc udźwignąc ciężaru konfrontacji ${ }^{57}$. Poza Jensem Schanze i Michaelem Saurem wszyscy pozostali korzystali z pomocy psychoterapeutów ${ }^{58}$.

Jednym z ubocznych skutków poszukiwań był także lęk o ewentualne odziedziczenie po przodku „złych genów" ${ }^{9}$. Niektórzy analizowali fizjonomię dziadka pod kątem fizycznego podobieństwa (rysy twarzy, jak u Uwe von Seltmanna, czy wysoki wzrost w przypadku Jennifer Teege), inni zastanawiali się nad ewentualnym podobieństwem psychicznym (, ,autorytarne rysy charakteru” u Michaela Saura) ${ }^{60}$.

Komponent procesu mierzenia się z przeszłością przodków stanowiła konfrontacja z postawą rodzin. Spośród sześciorga autorów prezentowanych prac komfort bezwarunkowego poparcia bliskich mieli: Jens Schanze ${ }^{61}$, Jennifer Teege ${ }^{62}$ oraz Michael

54 A. Senfft, Schweigen tut weh..., s. 41. Ludin wyratował także z opresji przyjaciela z czasów służby w Reichswerze i późniejszego komunistę, Richarda Scheringera. Zarówno Hahn, jak i Scheringer złożyli w 1947 r. (drogą korespondencyjną) odciążające wobec Ludina zeznania.

55 Z cytowanego w filmie listu Wilhelma Schülke do swej matki wynika, że bardzo ciężko przeżył wykluczenie i związany z nim zakaz wygłaszania ideologicznych „prelekcji”.

56 J. Teege, Amon..., s. 64-65.

57 U. von Seltmann, Gabi i Uwe..., s. 55, 57-59; C. Brunner, U. von Seltmann, Schweigen die Täter..., s. 54; J. Teege, Amon..., s. 27 i n. W toku poszukiwań Seltmanna wyszło na jaw prawdopodobieństwo uczestnictwa jego dziadka w tłumieniu powstania w warszawskim getcie.

58 Inaczej niż w przypadku dzieci nazistów, dokonujących swych rozliczeń w okresie wcześniejszym, obecna pomoc psychologiczna ma charakter ukierunkowany na rodziny z przeszłością nazistowską.

59 Pytanie o owe "geny” usłyszała np. Jennifer Teege podczas spotkania z grupą młodzieży izraelskiej u stóp pomnika obozu w Płaszowie. Zob.: J. Teege, Amon..., s. 263.

60 U. von Seltmann, Gabi i Uwe..., s. 35; J. Teege, Amon..., s. 56; K.O. Saur, M. Saur, Er stand im Hitlers Testament..., s. 178.

61 Wprawdzie matka reżysera miała obawy przed skutkami konfrontacji, ale od początku uczestniczyła aktywnie w jego przedsięwzięciu. Podobną postawę prezentował ojciec Jensa Schanze i jego starsze rodzeństwo.

62 J. Teege, Amon ..., s. 31, 32. W poszukiwaniach Teege była wspierana nie tylko przez męża, ale i adop- 
Saur ${ }^{63}$. Ojciec Uwe von Seltmanna nie był wprawdzie przeciwny poszukiwaniom, ale dopiero $w$ ich trakcie zaakceptował inicjatywę syna ${ }^{64}$. Bardziej skomplikowana była sytuacja Alexandry Senfft. W jej rodzinie od dawna toczył się spór o ocenę Hannsa Ludina ${ }^{65}$, zaś część krewnych kwestionowała tezę autorki książki o związku między przeszłością dziadka a problemami psychicznymi jej matki ${ }^{66}$. Z kolei Claudia Brunner rozpoczęła poszukiwania bez wiedzy bliskich. $\mathrm{O}$ ile matka i siostra zaakceptowały upublicznienie rodzinnej przeszłości, ojciec pozostał krytyczny ${ }^{67}$.

W przypadku większości członków badanej grupy poszukiwania przyniosły jednak ostatecznie uzdrowienie domowych relacji. Uwe von Seltmann przełamał barierę kontaktu z introwertycznym, choć w istocie bliskim sobie światopoglądowo ojcem ${ }^{68}$. Podobna integracja miała miejsce w przypadku rodziny Jensa Schanze. Michael Saur stał się bardziej wyrozumiały wobec wrażliwego emocjonalnie ojca. Alexandra Senfft dokonała symbolicznego pojednania ze zmarłą w latach 90. matką. Nawet Jennifer Teege zdołała nawiązać kontakt z niewidzianą przez lata Moniką Göth i swym biologicznym nigeryjskim ojcem. W jej przypadku integracja rodziny okazała się jednak niemożliwa, nie tyle ze względu na osobę dziadka, ile traumę "porzucenia” w okresie dzieciństwa ${ }^{69}$.

Wszyscy autorzy prezentowanych książek odkryli w toku poszukiwań więź z innymi przedstawicielami pokolenia wnuków, zarówno w obrębie rodziny, jak i poza nią. Dla Uwe von Seltmanna i Claudii Brunner owo poczucie solidarności zaowocowało decyzją o wspólnym wydaniu książki. Psychiczne problemy, towarzyszące procesowi konfrontacji z pamięcią, zbliżyły badaną grupę także z wnukami ofiar nazizmu. Claudia Brunner uczestniczyła w seminariach $\mathrm{z}$ udziałem potomków rodzin dotkniętych Holokaustem $^{70}$. Jennifer Teege, mająca licznych znajomych w Izraelu, zdołała pokonać barierę wstydu i odnowić przyjaźnie zadzierzgnięte w okresie studiów ${ }^{71}$. Uwe von Selt-

cyjnego brata.

63 Pomysł napisania książki był w istocie inicjatywą dwugeneracyjną - syna i wnuka.

64 U. von Seltmann, Gabi i Uwe..., s. 76-77. Niemal od początku Uwe von Seltmann miał poparcie części rodzeństwa ojca.

65 Kontrowersje w rodzinie Ludinów obrazuje film dokumentalny Malte Ludina 2 oder 3 Dinge, die ich von ihm weiss.

66 Postawę autorki książki popierali natomiast jej ojciec i brat. Zob.: A. Senfft, Schweigen tut weh..., s. 347-348. Matka Alexandry Senfft miała jako pierworodna córka bliski kontakt emocjonalny z ojcem. Po jego śmierci nigdy nie uporała się z rodzinnym dziedzictwem, w efekcie czego cierpiała na problemy emocjonalne. W wyniku choroby alkoholowej jej małżeństwo zakończyło się rozwodem, a dwójka dzieci cierpiała z powodu braku stabilnego dzieciństwa.

67 C. Brunner, U. von Seltmann, Schweigen die Täter..., s. 74-75, 78-79. Powodem oporów ojca Claudii Brunner był nie tylko argument „kalania” dobrego imienia rodziny, ale i obawa przed ewentualnym pochwyceniem stryja przez Interpol.

68 U. von Seltmann, Gabi i Uwe..., s. 115.

69 K.O. Saur, M. Saur, Er stand im Hitlers Testament..., s. 236, A. Senfft, Schweigen tut weh..., s. 343; J. Teege, Amon..., s. 175-192.

70 C. Brunner, U. von Seltmann, Schweigen die Täter..., s. 32-33.

71 J. Teege, Amon..., s. 235 i n. 
mann podczas jednego z pobytów w Polsce pokochał z wzajemnością i poślubił Polkę, Gabrielę Maciejowską - wnuczkę ofiary Majdanka i Auschwitz ${ }^{72}$.

Istotny efekt poszukiwań autorów prezentowanych książek stanowiło stawienie czoła poczuciu winy z powodu posiadania dziadka-nazisty. Mimo że nie poczuwali się do dziedziczenia grzechów przodków, większość z nich pogłębiła - deklarowaną już wcześniej - świadomość odpowiedzialności pokolenia wnuków. Najdobitniej wyraził to Uwe von Seltmann we wstępie do książki Schweigen die Täter, reden die En$\mathrm{kel}$. W jego opinii autorom prac rozliczeniowych nie chodzi o potrzebę ekspiacji, lecz o wewnętrzny ład moralny. Problem polega na tym, że, rozliczając rodzinną przeszłość, nie potrafią nie myśleć o ciężarze niemieckiej historii w wymiarze globalnym. Właśnie owa świadomość stanowi powód publikowania wyników poszukiwań w formie książek. Upubliczniając rodzinne historie, chcą uświadamiać swej generacji nie tylko sens „odpominania" przeszłości, ale i wagę dokonywanych w życiu wyborów - tak aby uniknąć błędów swoich własnych dziadków ${ }^{73}$.

Nie sposób ocenić stopnia skuteczności opisanego wyżej przesłania. Coraz większe zapotrzebowanie w Niemczech na bolesne w treści, a wartościowe w konkluzjach prace potomków pokolenia „sprawców” zdaje się dowodzić rosnącej potrzeby rozmawiania o historii, także w wymiarze prywatnym. Przynajmniej część pokolenia wnuków nie chce już dłużej milczeć lub upiększać rodzinnej przeszłości, chce prawdy, dla siebie i dla swych dzieci.

\section{BIBLIOGRAFIA}

Bar-On D., Die Last des Schweigens. Gespräche mit Kindern von Nazi-Tätern, Reinbek bei Hamburg 2003.

Bode S., Kriegsenkel. Die Erben der vergessenen Generation, Stuttgart 2013.

Brunner C., Seltmann U. von, Schweigen die Täter, reden die Enkel, Frankfurt am Main 2005.

Himmler K., Himmler ijego bracia. Historia niemieckiej rodziny, posł. M. Wildt, przet. W. Łygaś, Warszawa 2006.

Kessler M., „Ich muß doch meinen Vater lieben, oder?” Die Lebensgeschichte von Monika Göth, Tochter des KZ-Kommandanten aus "Schindlers Liste”, Frankfurt am Main 2002.

Müller-Hohagen J., Geschichte in uns. Seelische Auswirkungen bei den Nachkommen von NS-Tätern und Mitläufern, Berlin 2002.

Reichel P., Schmid H., Steinbach P., Der Nationalsozialismus - die zweite Geschichte, München 2009.

Seltmann U. von, Todleben. Eine deutsch-polnische Suche nach der Vergangenheit, München 2010. Seltmann U. von, Gabi i Uwe. Mój dziadek zginąt w Auschwitz. A mój byt esesmanem, Warszawa 2012, Pokolenie Sprawców. Pokolenie Ofiar. Literatura Faktu PWN.

Saur K.O., Saur M., Er stand im Hitlers Testament. Ein deutsches Familienerbe, Berlin 2007.

72 U. von Seltmann, Gabi i Uwe..., s. 93-95.

73 C. Brunner, U. von Seltmann, Schweigen die Täter..., s. 12-13. 
Senfft A., Schweigen tut weh. Eine deutsche Familiengeschichte, Berlin 2009.

Teege J., Amon. Mein Grossvater hätte mich erschossen, Reinbek bei Hamburg 2013, Sachbuch $B V, 06493$.

Welzer H., Sprawcy. Dlaczego zwykli ludzie dokonuja masowych mordów, współpr. M. Christ, przeł. M. Kurkowska, Warszawa 2010, Kroki/Schritte.

Welzer H., Moller S., Tschuggnall K., „Opa war kein Nazi”. Nationalsozialismus und Holocaust im Familiengedächtnis, Frankfurt am Main 2002, Zeit des Nationalsozialismus.

Prof. Katarzyna JEDYNAKIEWICZ-MRÓZ - doktor habilitowana, historyczka, niemcoznawczyni, profesor w Instytucie Historii UŁ. Tematyka badawcza: dzieje niemieckiej emigracji antynazistowskiej, kwestia przezwyciężania nazistowskiej przeszłości w RFN, historia kobiet w Niemczech w XX wieku. Najnowsza publikacja książkowa: Zawsze pod prad. Życie Eryki Mann (2013). 